\title{
Editor Note-Journal of Blood and Lymph
}

\section{Sameera Peraramelli*}

Department of Hematology, Stanford School of Medicine, USA

*Corresponding author: Peraramelli S, Department of Hematology, Stanford School of Medicine, 269 Campus Drive, Stanford, CA, USA, Tel: +1 603-943-2442; E-mail: Sameerap@stanford.edu

Received date: Mar 28, 2018; Accepted date: Mar 29, 2018; Published date: Mar 30, 2018

Copyright: (c) 2018 Peraramelli S. This is an open-access article distributed under the terms of the Creative Commons Attribution License, which permits unrestricted use, distribution, and reproduction in any medium, provided the original author and source are credited.

Citation: Peraramelli S (2018) Editor Note-Journal of Blood and Lymph. J Blood Lymph 8: e125. doi:10.4172/2165-7831.1000e125

\section{Editor Note}

Blood and lymph are two specialized body fluids with varied functions. Blood is composed of plasma, red and white blood cells and platelets. Major functions of blood are to regulate the body temperature, maintain constant $\mathrm{pH}$ and water balance, transportation of respiratory gases, digested food and waste materials. Blood protects body from loss of blood by clotting. Lymph however, serves as middleman between blood and tissues. It transports digested fats and vitamins. It disposes bacteria and foreign particles thereby defending body against diseases. Damage or defects in lymphatic or circulatory system leads to serious infections, sickness and diseases.

Journal of Blood and Lymph is an international peer reviewed journal with open access. Journal publishes articles related to blood coagulation disorders, hematological malignancies, B- and T-cell lymphomas, case reports on rare clinical observations and many more. In the current volume 7, issue 4 journal has successfully published 12 articles which include 4 case reports, 3 research articles, 2 opinion articles, one each of short communication, review article and editorial. In the case reports, Nassabein et al. [1] showed two very interesting and rare studies on the composite lymphomas. In another case study, Becilli et al. [2] showed that Wernicke-Korsackoff syndrome which is frequently misdiagnosed was found in a T-ALL patient. With the help of MRI of brain they confirmed and by administering high thiamine dose they could completely resolve the symptoms of the syndrome. Sakamoto et al. [3] showed the importance of cytogenetic analysis and immunophenotyping for accurate accessment of DHL and AML. Finally, Micco et al. [4] reported an important information on the juvenile VTE drug dosage.

In the research articles, Nwabuko et al. [5] studies showed no increase in immune sensitivity in hypertensive patients on therapy when compared to control population not on therapy. Annibali et al. [6] showed that indeed Zolendronic acid reduces PDGF in vivo. Shoikhedbrod [7] described the importance of development of new lymphosorption technology for everyday use to convert entire lymph in cancerous patients into lymph of healthy person. Nakase et al. [8] through their previous research discussed about the importance of CD25+ AML for effective diagnosis and treatment of AML. Malvandi [9] discussed about the risks of low concentration of toxins in food and how they are generally neglected which causes serious food-borne diseases.
In a well-written review from Hariharan et al. [10] they described the complications associated with cancer development and cancer management that clinicians must be aware of. A short communication on blood group and diet pyramid written by Hussain et al. [11] is very informative for our current life style.

Lastly, in the editorial written by Wiwanitkit [12] discusses about the discrepancy in eosinophil count in Zika virus infection suggesting for a though clinical analysis.

\section{References}

1. Nassabein R, Fleifel S, Bejjani N, Ghanem H, Gerges DA, et al. (2017) Composite Hodgkin and Non-Hodgkin Lymphomas: Report of Two Cases with Unusual Presentations. J Blood Lymph 7: 180.

2. Becilli M, Pagano A, Mallio CA, Annibali O, Armiento D, et al. (2017) Wernicke's Encephalopathy in A Young Adult Affected by T Cell Acute Lymphoblastic Leukemia and Ileotiphlytis with Review of the Literature. J Blood Lymph 7: 182.

3. Sakamoto D, Satoh N, Ohnishi H, Yamasaki S, Watanabe T, et al. (2017) Simultaneous Occurrence of Double-Hit Lymphoma and Acute Myeloid Leukemia in Bone Marrow. J Blood Lymph 7: 188.

4. Di Micco P, Di Micco G (2017) Safety of Low Dose of Edoxaban to Treat Acute and Long Term Treatment of a VTE Occurred in a Very Young Adolescent. J Blood Lymph 7: 191.

5. Nwabuko OC, Chukwuonye II, Nwabuko MG (2017) A Prospective Assessment of Autoimmune Sensitization of Hypertensive Patients on Antihypertensive Therapy: A Hospital Based Study. J Blood Lymph 7: 183.

6. Annibali O, Petrucci MT, Tirindelli MC, Giannetti B, Vincenzi B, et al. (2017) Cytokines Behavior in Multiple Myeloma Patients during Zoledronic Acid Treatment. J Blood Lymph 7: 184.

7. Shoikhedbrod M (2017) The New Method of Lymphosorption for Patient's Treatment. J Blood Lymph 7: 190.

8. Nakase K, Kita K, Katayama N(2017) Prognostication of Acute Myeloid Leukemia Needs Incorporation of CD25 Status. J Blood Lymph 7: 185.

9. Malvandi AM (2017) Public Health Risks Associated with Low Concentration of Food-Borne Toxins. J Blood Lymph 7: 187.

10. Hariharan U, Natarajan V (2017) Critical Care Management and Newer Therapies for Tumour Lysis Syndrome. J Blood Lymph 7: 189.

11. Hussain S, Raza Q, Fatima I, Zahra SM, Rashid F (2017) Obesity is an Eating Disorder not a Disease. J Blood Lymph 7: 181.

12. Wiwanitkit V (2017) Eosinophil in Zika Virus Infection. (2017) J Blood Lymph 7: e124. 